\title{
Trioxifene Mesylate
}

National Cancer Institute

\section{Source}

National Cancer Institute. Trioxifene Mesylate. NCI Thesaurus. Code C1414.

A mesylate salt form of trioxifene, a nonsteroidal selective estrog en receptor modulator (SERM). Trioxifene competitively inhibits the binding of estradiol to estrogen receptor alpha (ER alpha), resulting in ER alpha-mediated gene expression. Clinical development of Trioxifene has not proceeded because of lack of superior results over tamoxifen and side effect profile. $(\mathrm{NCl})$ 